\title{
IMPLIKASI HUKUM JATUHNYA PENERBANGAN UDARA MILITER TERHADAP MASYARAKAT SIPIL DI NEGARA INDONESIA
}

\author{
Zakaria Abdillah Abud \\ Universitas Negeri Surabaya \\ Zakaria.18066@mhs.unesa.ac.id
}

\begin{abstract}
ABSTRAK
Jatuhnya penerbangan udara militer seringkali terjadi di wilayah negara Indonesia karena berbagai faktor kesalahan. Kesalahan penerbangan militer dengan pesawat atau helicopterakan berdampak pada kerugian internal dan eksternal yang menimpa masyarakat sipil di negara Indonesia. Pertanggungjawaban hukum merupakan iktikad baik dari implikasi untuk berkompensasi dengan dasar besarnya kerugian yang dialami. Tujuan penelitian untuk mengetahui besaran kesepakatan kerugian dalammencapai tujuan hukum yang pasti atas implikasi peristiwa penerbangan militer yang jatuh menimpa masyarakat. Jenis penelitian yang dipergunakan adalah penelitian normatif dengan metode kekaburan norma. Metode kekaburan norma memberikan ketidakpastian sebuah dasar hukum yang pasti terhadappemberian besaran ganti kerugian kepada korban sipil. Hasil penelitian ini menunjukkan bahwa disetiap kecelakaan yang terjadi berakibat hukumyang menitikberatkan dasar bahwa penyelesaian terjadi dilakukan dengan kesepakatan pihak melihat secara fisik, langsung serta biaya-biaya yang dikeluarkan untuk melakukan kegiatan pertolongan dan pembersihan kepada masyarakat.
\end{abstract}

Kata kunci: Pertanggungjawaban, Ganti Rugi, Penerbangan Militer, Masyarakat Sipil

\section{ABSTRACT}

The fall of military air flights often occurs in the territory of the Indonesian state due to various factors of error. Military flight errors with military aircraft or helicopters that occur not only cause losses but also have a negative impact on civil society in Indonesia. Legal liability is a form of good faith from the implications in the return of compensation on the basis of the magnitude of the loss experienced. The purpose of the study was to determine the amount of the total loss agreement in achieving a definite and clear legal goal on the implications of the military aviation tragedy that fell on the community. The type of research conducted by the author is normative research with the method used is norm ambiguity. The method of obscurity of norms gives uncertainty a clear 
legal basis in providing compensation for civilian victims. The problem in answering the issues raised is through the Legislative and Conceptual Approach. The results of this idea research show that every accident that occurs results in loss to the community, emphasizing the basis that the settlement occurs with the agreement of the parties to see physically, directly and the costs incurred to carry out rescue and cleaning activities.

Keywords: Accountability, Indemnity, Military Aviation, Civil Society.

\section{Latar Belakang}

Kendaraan penerbangan militer Indonesia bersifat privasi, karena alat pengangkutan udara tersebut bersifat untuk kegiatan pertahanan negara non komersial dan mengangkut bendabenda rahasia untuk kepentingan negara. Hal ini tidak bisa disamakan seperti penerbangan angkutan niaga. Penerbangan militer meliputi berbagai jenis alat angkutan udara yang berbeda-beda pula seperti kendaraan pesawat terbang militer, helicopter militer ataupun jet tempur milik militer.Kemudian daripada itu kesalahan akan menyebabkan kecelakaan akan menimbulkan pelanggaran pada suatu Peraturan Pemerintah Republik Indonesia Nomor 3 Tahun 2001 Tentang Keamanan Dan Keselamatan Penerbangankarena telah jelas sebagaimana standart pengoperasional dalam hal mengendalikan penerbangan udara harus didasarkan pokok-pokok keamanan dan keselamatan bagi pihak pengoperasional serta pihak-pihak lain. Potensi kecelakaan akan terjadi karena berbagai faktor kesalahan yang mungkin tidak adanya unsur yang dipenuhi dalam Peraturan Pemerintah tentang keamanan dan keselamatan penerbangan serta faktor-faktor disengaja ataupun tidak disengaja. Faktor kesengajaan dapat terlihat bahwa pengendalian penerbangan udara tersebut telah mengalami ketidakmampuan dalam hal mengemudikan awak penerbangan dengan selamat seperti mengatur besaran kecepatan, arah navigasi dan lainnya. Sebaliknya pada faktor ketidaksengajaan dapat terlihat jelas terjadi pada kelalaian dalam melakukan persiapan untuk penerbangan udara. Kondisi itu akan mengkhawatirkan sesuatu hal buruk terjadi kepada pihak-pihak lainnya. Sesuatu hal yang buruk pastilah menimbulkan kerugian yang sangat besar ternilai bahkan tidak dapat ternilai. Kerugian yang ternilai adalah 
harta benda yang telah musnah karena kejadian tersebut, sedangkan kerugian yang tidak dapat ternilai adalah nyawa yang terselamatkan ataupun tidak terselamatkan. Dalam beberapa tahun berlalu berbagai kecelakaan penerbangan udara militer telah banyak terjadi. Seperti halnya dilansir dari sumber berita harian CNNIndonesia.com pada tanggal 15 Juni Tahun 2020 yang berjudul TNI AU Ganti Rugi Rumah Warga yang Tertimpa Pesawat di Riau. Kepala Staf Angkatan Udara (KSAU), Marsekal TNI Fadjar Prasetyo menyatakan "Pihaknya bakal mengganti rugi pada warga yang rumahnya tertimpa pesawat tempur BAE Hawk 209. Dia juga menyampaikan permintaan maaf atas insiden yang terjadi." Pesawat BAW Hawk 209 terjatuh saat hendak ke Lanud Roesmin Nurjadin usai latihan di wilayah Kampar, Riau. Ada tiga pesawat. Namun, pesawat terakhir yang dikendarai Lettu PNB Afrianto Ismail mengalami gangguan. Pilot meminta izin mendarat darurat karena lampu peringatan menyala. Pesawat lalu menghantam sejumlah rumah. Salah satu pemilih rumah yakni Abun mengaku bersyukur sedang tidak berada di rumah saat insiden terjadi.
Selain itu bersumber berita Merdeka.com(pada tanggal 20 Mei 2009 Bahwa Pesawat Hercules L-10030 bernomor registrasi A-1325, yang mengangkut sejumlah tentara dan keluarganya mengalami kecelakaan di Magetan, Jawa Timur. Pesawat yang dipiloti Mayor Penerbang Danu Setiawan ini menabrak permukiman dan ladang yang menewaskan 98 penumpang dan 2 warga setempat.

Penyelesaian terhadap kasus tersebut harus didasarkan pada iktikad baik para pihak yang didasarkan pada hati nurani yang berkemanusiaan dan berkeadilan. Sebab untuk mencapai kesepakatan antara pihak harus pula didasarkan pada hukum yang mengatur dengan jelas dan pasti. Pengaturan hukum dalam memberikan implikasi solusi itu akan membawa dampak baik dan adil bagi korban yang dirasa dirugikan karena kepentingannya. Pemberian kompensasi kepada korban dapat ternilai baik jika dalam pelaksanaan kesepakatan itu telah diberikan rasa kepuasan atas tanggung jawabnya selama hal itu telah dilaksanakan.

Namun kompensasi yang diberikan bukan hanya membawa dampak sosial bahwa korban telah berkehendak menerima namun harus 
didasarkan pula pada dampak hukum kepada korban yang tidak menerima pemaksaan besaran ganti rugi yang tidak sesuai dengan keadaan dan kepentingannya yang dirugikan. Sehingga hal ini memunculkan isu berbagai penyelesaian kasus yang telah dipaparkan ke dalam bentuk metode penelitian hukum yang ada. Metode yang digunakan dalam penelitian hukum ini akan memberikan gambaran jelas untuk menjawab persoalan yang terjadi di masyarakat sipilnegara Indonesia sebab perlindungan masyarakat sipiltersebut sebagai korban adalah penting dalam menjunjung tinggi hak dan kewajibannya yang sebagaimana konstitusi pasal 28 UUD Negara Republik Indonesia Tahun 1945 menjelaskan bahwa setiap orang memiliki hak yang melekat pada dirinya yang harus dipenuhi yakni Hak Asasi Manusia. Persoalan jurnal ini akan membahas secara detail penyelesaian perkara yang terjadi di masyarakat karena jatuhnya penerbangan militer dengan merumuskan masalah antara lain bagaimana kompensasi yang diberikan kepada korban.Sehingga dalam penjabaran latar permasalahan tersebut maka penulis memberikan suatu gagasan ilmu hukum berupa bagaimana analisishukum dalam menyelesaikan pertanggungjawaban penerbangan militer kepada pihak korban yang merasa dirugikan akibat perbuatan melawan hukum jatuhnya penerbangan militer serta bagaimana tolak ukur kompensasi yang diberikan dalam memberikan kerugian kepada korban berdasarkan hukum yang berlaku?

\section{Metode Penelitian}

Penelitian merupakan suatu kegiatan ilmiah yang didasarkan pada analisis dan konstruksi yang dilakukan secara sistematis, metodologis dan konsisten dan bertujuan untuk mengungkapkan kebenaran sebagai salah satu manifestasi keinginan manusia untuk mengetahui apa yang sedang dihadapinya (Soerjono Soekanto:1986). Jenis metode penelitian yang digunakan adalah penelitian normatif. Penelitian hukum normatif adalah suatu proses untuk menemukan suatu aturan hukum, prinsip prinsip hukum, maupun doktrin-doktrin hukum yang dihadapi dan Penelitian ini dilakukan untuk menghasilkan argumentasi, teori atau konsep baru sebagai preskripsi dalam menyelesaikan masalah (Peter Mahmud Marzuki, 2011:35). Tehnik 
pengumpulan data dilakukan dengan studi bahan hukum primer, bahan hukum sekunder ataupun bahan hukum tersier. Analisis data dalam penelitian ini adalah menggunakan sifat deksriptif yang merupakan penulis memberikan analisis dalam menggambarkan atau memaparkan atas subjek dan objek penelitian yang sebagaimana hasil penelitian yang dilakukan penulis. Pendekatan yang digunakan peneliti sebagai acuan bahan penelitian adalah pendekatan perundang-undangan

(Statue Approach)dan pendekatan konseptual (conceptual approach). Pendekatan perundang-undangan ini merupakan penelitian yang mengutamakan bahan hukum yang berupa peraturan perundang-undangan sebagai bahan acuan dasar dalam melakukan penelitian. Peneliti menggunakannya sebagai peraturan perundangundangan yang dalam penormaannya masih terdapat kekurangan atau membuat praktek penyimpangan baik dalam tataran teknis atau dalam pelaksanannya di lapangan. Pendekatan ini dilakukan dengan menelaah semua peraturan perundangundangan yang bersangkut paut dengan permasalahan (isu hukum) yang sedang dihadapi. Misalnya dilakukan dengan mempelajari konsistensi/kesesuaian antara Undangundang dasar dengan Undang-Undang, Undang-undang yang satu dengan Undang-undang lainnya.

Pendekatan konseptual adalah jenis pendekatan penelitian yang memberikan sudut pandang analisa penyelesaian permasalahan dalam penelitian hukum dilihat dari aspek konsep-konsep hukum yang melatarbelakanginya, atau bahkan dilihat dari nilai-nilai yang terkandung dalam penormaan sebuah peraturan yang kaitannya dengan konsep-konsep yang digunakan. Sebagian besar jenis penelitian ini dipakai untuk memahami konsep-konsep yang berkaitan dengan penormaan dalam suatu perundang-undangan apakah telah sesuai dengan ruh yang terkandung dalam konsep-konsep hukum yang mendasarinya. Pendekatan ini beeanjak pada pandangan adan doktrin yang berkembang di dalam ilmu hukum dengan memberikan pengertianpengertian hukum, konsep hukum, maupun asas hukum yang relevan dengan permasalahan.

Bahan hukum primer dalam penelitian ini diperoleh Bahan hukum yang penulis gunakan dalam penelitian 
ini adalah bahan hukum primer dan bahan hukum sekunder. Penelitian ini menggunakan bahan hukum primer berupa peraturan perundang-undangan dan serta sumber hukum formil lainnya.Bahan hukum sekunder yang digunakan dalam penelitian ini adalah buku-buku, jurnal hukum, dan internet yang berkaitan dengan permasalahan jurnal hukum udara ini.

Analisa yang digunakan terhadap bahan-bahan hukum yang terkumpul adalah Undang-Undang No.1 Tahun 2009 Tentang Penerbangan, Undang-undang No.21 Tahun 2013 Tentang Keantariksaan, Undang-Undang Republik Indonesia No. 43 Tahun 2008 Tentang Wilayah Negaraserta Peraturan Pemerintah Republik Indonesia Nomor 3 Tahun 2001 Tentang Keamanan dan Keselamatan Penerbangandengan dianalisis secara preskriptif, yakni merumuskan dan mengajukan pedoman-pedoman dan kaedah-kaedah yang harus dipatuhi oleh praktek hukum dan dogmatik hukum, dan bersifat kritis yang selanjutnya digunakan untuk memecahkan permasalahan yang dihadapi. Analisa bahan hukum dilakukan dengan cara melakukan seleksi data sekunder atau bahan hukum, kemudian melakukan klasifikasi menurut penggolongan bahan hukum dan menyusun data hasil penelitian tersebut secara sistematis yang dilakukan secara logis. Artinya, ada hubungan keterkaitan antara bahan hukum satu dengan bahan hukum lainnya untuk mendapatkan gambaran umum dari hasil penelitian (Mukti Fajar dan Yulianto Achmad:2010/181)

\section{Hasil dan Pembahasan}

\section{A. Pertanggung Jawaban}

Penerbangan Militer Yang Jatuh

dan Mengakibatkan Kerugian

Bagi Masyarakat Indonesia

Analisis hukum pertanggung jawaban penerbangan militer yang jatuh dan mengakibatkan kerugian bagi masyarakat Indonesia diatur pada hukum nasional penerbangan negara Indonesia pada peraturan perundangundangan yang lebih lanjut pada Undang-undang Republik Indonesia No.1 Tahun 2009 Tentang Penerbangan. Sebab jatuhnya penerbangan militer yang diangkat adalah di wilayah Negara Kesatuan Republik Indonesia.

Untuk dapat menentukan kedaulatan wilayah negara Indonesia maka secara garis umum sebagaimana di atur pada Pasal 1 ayat (1) UndangUndang Republik Indonesia Nomor 43 Tahun 2008 Tentang Wilayah Negara 
bahwa "Wilayah Negara Kesatuan Republik Indonesia, yang selanjutnya disebut dengan Wilayah Negara adalah salah satu unsur negara yang merupakan satu kesatuan wilayah daratan, perairan pedalaman, perairan kepulauan dan laut teritorial beserta dasar laut dan tanah di bawahnya, serta ruang udara di atasnya, termasuk seluruh sumber kekayaan yang terkandung di dalamnya."

Selanjutnya secara geografis wilayah Indonesia diatur pada pasal 5 Undang-Undang Republik Indonesia Nomor 43 Tahun 2008 Tentang Wilayah Negara berbunyi "Batas Wilayah Negara di darat, perairan, dasar laut dan tanah di bawahnya serta ruang udara di atasnya ditetapkan atas dasar perjanjian bilateral dan/atau trilateral mengenai batas darat, batas laut, dan batas udara serta berdasarkan peraturan perundang-undangan dan hukum internasional." Serta ketentuan lebih lanjut pada pasal 6 ayat (1)Undang-Undang Republik Indonesia Nomor 43 Tahun 2008 Tentang Wilayah Negara berbunyi bahwa Batas Wilayah Negara sebagaimana dimaksud dalam Pasal 5 , meliputi: a. Di darat berbatas dengan Wilayah Negara: Malaysia, Papua Nugini, dan Timor Leste;

b. Di laut berbatas dengan Wilayah Negara: Malaysia, Papua Nugini, Singapura, dan Timor Leste; dan

c. Di udara mengikuti batas kedaulatan negara di darat dan di laut, dan batasnya dengan angkasa luar ditetapkan berdasarkan perkembangan hukum internasional.

Namun dalam pembahasan ini lebih menitikberatkan pada permasalahan penerbangan militer. Secara garis besar penjelasan penerbangan terdapat pada berdasarkan pasal 1 ayat (1) UndangUndangNo. 1 Tahun 2009 Tentang Penerbangan bahwa "Penerbangan adalah satu kesatuan sistem yang terdiri atas pemanfaatan wilayah udara, pesawat udara, bandar udara, angkutan udara, navigasi penerbangan, keselamatan dan keamanan, lingkungan hidup, serta fasilitas penunjang dan fasilitas umum lainnya." Analisis untuk menghasilkan pokok bahasan dalam isu ini adalah perbuatan hukum, subjek hukum, serta dasar hukum yang digunakan dalam menyelesaikan perkara jika dalam penerbangan yang dimaksud 
mengalami ketidakselamatan hingga kerusakan fasilitas umum tersebut.

Selain itu penyelesaian perkara berlatar belakang penerbangan militer jatuh menimpa masyarakat sipil di negara Indonesia harus bertumpu pada titik pada unsur-unsur hukum yang mengikat didalamnya seperti bentuk perbuatannya akan pertanggungjawaban hukum, tolak ukur kompensasi yang disepakati menurut hukum yang berlaku, serta syarat kesepakatan dalam perjanjian. Sebab jika tidak adanya pertanggungjawaban hukum maka tidak akan dapat diketahui pihak manakah tersebut yang berhakmelaksanakan kewajibannya sebagaimana perbuatan yang telah dilakukannya atau pihak yang kemudian dapat digugat.(Johan, 2010)

Berdasarkan teori hukum umum, pertanggungjawaban hukum menyatakan bahwa setiap orang, termasuk pemerintah, harus mempertangungjawabkan setiap tindakannya, baik karena kesalahan atau tanpa kesalahan (Munir Fuady, 2009: 147). Selain itu Dalam pengertian dan penggunaan praktis, istilah liability menunjuk pada pertanggungjawaban hukum, yaitu tanggung gugat akibat kesalahan yang dilakukan oleh subyek hukum (H.R.
Ridwan, 2006: 335). Maka dalam teori tersebut dapat di implikasi hukum dalam jatuhnya penerbangan udara militer adalah termasuk kategori Perbuatan Melawan Hukum dengan subjek hukum adalah Pemerintah Kementrian Pertahanan Republik Indonesia.

Perbuatan Melawan Hukum dapat memberikan kerugian (Soesilo: 2008/306). Perbuatan Melawan hukum diatur dalam Pasal 1365 dan Pasal 1366 KUHPerdata.Dalam Pasal 1365 KUHPerdata memberikan ketentuan dan makna hukum tentang Perbuatan Melawan Hukum yakni "tiap perbuatan melawan hukum, yang mendatangkan kerugian pada seorang lain, mewajibkan orang yang karena salahnya menerbitkan kerugian itu, mengganti kerugian tersebut". Ketentuan selanjutnya tertuang dalam Pasal 1366 KUHPerdata adalah "setiap orang bertanggung jawab, tidak saja untuk kerugian yang disebabkan karena perbuatanya, tetapi juga untuk kerugian yang disebabkan karena kelalaianya atau kurang hatihatianya" Sehingga unsur-unsur bahwa itu termasuk Perbuatan Melawan Hukum karena:

1. Adanya subjek hukum yang jelas yakni Manusia atau badan hukum 
(Pemerintah

Kementrian

Pertahanan Republik Indonesia)

2. Adanya perbuatan yang disengaja atau kelalaian dalam melanggar suatu peraturan perundangundangan atau karena kehatihatiannya (angkutan udara penerbangan militer jatuh).

3. Adanya kerugian yang timbul diantara pihak tersebut (Segala harta benda lainnya oleh masyarakat musnah).

Perbuatan Melawan Hukum dalam arti luas dapat diartikan dengan cukup luas yaitu (Rosa Agustina:2003/53):

1. Melanggar hak subyektif orang lain, berarti melanggar wewenang khusus yang diberikan oleh hukum kepada seseorang. Yurisprudensi memberi arti hak subyektif sebagai berikut:

a. Hak Perorangan seperti kebebasan, kehormatan, nama baik serta hak untuk hidup.

b. Hak atas harta kekayaan, kebendaan dan hak mutlak lainya untuk menguasai dan atau memiliki.

Suatu pelanggaran terhadap hak subyektif orang lain merupakan perbuatan melawan hukum apabila perbuatan itu secara langsung melanggar hak subyektif orang lain, dan menurut pandangan dewasa ini disyaratkan adanya pelanggaran terhadap tingkah laku, berdasarkan hukum tertulis maupun tidak tertulis yang seharusnya tidak dilanggar oleh pelaku dan tidak ada alasan pembenar menurut hukum.

2. Bertentangan dengan kewajiban hukum pelaku. Kewajiban hukum diartikan sebagai kewajiban yang berdasarkan hukum baik tertulis maupun tidak tertulis (termasuk dalam arti ini adalah perbuatan pidana pencurian, penggelapan, penipuan, dan pengrusakan).

3. Bertentangan dengan kaedah kesusilaan, yaitu bertentangan dengan norma-norma moral, sepanjang dalam kehidupan masyarakat diakui sebagai norma hukum. Utrecht menulis bahwa yang dimaksudkan dengan kesusilaaan ialah semua norma yang ada didalam kemasyarakatan, yang tidak merupakan hukum, kebiasaan atau agama.

Kemudian pandangan akan pertanggungjawaban hukum akibat peristiwa tersebut dapat didasarkan pada 
pasal 1 ayat (5) Undang-Undang Republik Indonesia Nomor 21 Tahun 2013 Tentang Keantariksaan berbunyi bahwa "Penyelenggara Keantariksaan adalah pihak atau subjek yang melaksanakan Penyelenggaraan Keantariksaan.” Lalu pada Pasal 76 (1) Undang-Undang Republik Indonesia Nomor 21 Tahun 2013 Tentang Keantariksaan berbunyi bahwa "Pemerintah Republik Indonesia bertanggung jawab secara internasional atas setiap Penyelenggaraan Keantariksaan yang dilakukan di wilayah kedaulatan dan/atau wilayah." Sehingga hal inimemberikan makna bahwa perbuatan tersebut harus disertai pertanggungjawaban hukum karena perilakunya yang melawan hukum atau melanggar peraturan perundangundangan tersebut.

Penyelesaian perkara tersebut akan kompensasi ganti rugi berdasarkan hukum yang berlaku adalah didasarkan pada Pasal 77 Undang-Undang Republik Indonesia Nomor 21 Tahun 2013 Tentang Keantariksaan Berbunyi bahwa:

(1) Tanggung jawab terhadap Kerugian yang ditimbulkan oleh Penyelenggaraan Keantariksaan yang terjadi di permukaan bumi atau pada pesawat udara yang sedang dalam penerbangan bersifat mutlak.

(2) Tanggung jawab terhadap Kerugian yang terjadi di Antariksa dan/atau terhadap wahana Antariksa di antara sesama Penyelenggara Keantariksaan didasarkan atas adanya unsur kesalahan.

(3) Tanggung jawab terhadap Kerugian di antara sesama Penyelenggara Keantariksaan sebagaimana dimaksud pada ayat (2) ditetapkan berdasarkan perjanjian para pihak.

Pasal 77 ayat (1), (2), dan (3) Undang-Undang Republik Indonesia Nomor 21 Tahun 2013 Tentang Keantariksaan memberikan sebuah jawaban bahwa pertanggungjawaban hukum atas perbuatan melawan hukum tersebut memiliki makna bahwa harus atau diwajibkan memberikan kompensasi atas pertanggungjawabannya melakukan kesalahan karena pertanggungjawaban tersebut bersifat mutlak serta penyelesaian perkara tersebut dapat diselesaikan dengan cara kesepakatan para pihak terdahulu dalam suatu perjanjian yang mengikat.

Untuk mencapai kesepakatan dalam memberikan ganti rugi yang mutlak adalah tanggung jawab hukum maka harus disertai langkah-langkah beriktikad baik kepada pihak korban. Hadirnya rasa iktikad baik akan 
membawa suasana di para pihak tidak boleh merasa dirinya adalah pihak yang sangat dirugikan tetapi harus berimbang yang adil dengan melihat kejadiannya dilapangan.

\section{Tolak Ukur Kompensasi Terhadap Kerugian Yang Dialami Masyarakat}

Analisis hukum terhadap tolak ukur kompensasi terhadap kerugian yang dialami masyarakatyang harus diberikan akibat jatuhnya penerbangan udara militer berdasarkan pada Pasal 79 ayat (3)Undang-Undang Republik Indonesia Nomor 21 Tahun 2013 Tentang Keantariksaan berbunyi bahwa "Kerugian sebagai akibat dari kegiatan Keantariksaan yang dapat dimintakan kompensasinya adalah Kerugian yang bersifat fisik dan langsung, termasuk biaya-biaya yang dikeluarkan untuk melakukan kegiatan pertolongan dan pembersihan."

Hal ini memaksudkan bahwa bentuk kompensasi yang dimana pertanggungjawaban hukum dilaksanakan atas kesepakatan beriktikad baik maka harus dilakukan lebih dahulu adalah pemenuhan kesehatan untuk segera tertolong jika dalam keadaan tersebut adanya korban jiwa serta jika dalam keadaan tersebut tidak ada korban jiwa sama sekali maka dalam memberikan kompensasi ganti kerugian adalah dengan cara membersihkan lingkungan tempat dimana dampak penerbangan udara militer jatuh menjadi rusak serta melakukan pembayaran biaya-biaya yang korban minta sesuai bukti kerugian.

Bukti kerugian tidak serta merta hanya dipandang akan penguasaan dan status kepemilikannya namun juga harus didasarkan pada kerugian yang sifatnya fisik (bagian diri tubuh) serta kerugian langsung (kerugian yang dapat dilihat secara langsung karena perbuatannya). Sehingga untuk mengetahui besaran nominal ganti kerugian agar dapat diketahui masyarakat maka hanya dapat didasarkan atas perjanjian kesepakatan para pihak dengan melihat biaya fisik dan biaya langsung yang telah telah terjadi.

Para pihak yang dirasa tidak merasa puas dan adil karena kompensasi yang diberikan dapat mengajukan permohonan dengan caracara penyelesaian perkara perdata litigasi dan non litigasi seperti mediasi, konsiliasi, arbitrase dan lainnya agar tercapainya tujuan hukum akan keadilan dan kepastian hukum dalam kompensasi yang didapatkan. 
Selain itu kewajiban yang dilakukan adalah sebagai bentuk pemenuhan dalam memenuhi kewajiban terhadap undang-undang tentang keamanan dan keselamatan yang sebagaimana diatur pada Peraturan Pemerintah Republik Indonesia Nomor 3 Tahun 2001 Tentang Keamanan Dan Keselamatan Penerbangan.Disisi lain bentuk kompensasi para pihak yang merasa menjadi korban maka akan mendapatkan pertolongan dan bantuan pencarian oleh badan SAR nasional yang sebagaimana dituangkan pada Bab IX Pencarian dan Pertolongan Kecelakaan pasal 93 Peraturan Pemerintah Republik Indonesia Nomor 3 Tahun 2001 Tentang Keamanan Dan Keselamatan Penerbangan.

\section{Kesimpulan}

Berdasarkan hasil penelitian mengenai kecelakaan penerbangan udara militer yangberimplikasi hukum kepada masyarakat sipil di Indonesiadengan memberikan dampak kerugian secara materiil dan hukum. Dalam segi kerugian materiil dapat dilihat dari harta benda dan nyawa yang hilang serta dari segi hukum adalah kemanfaatan, keadilan dan kepastian hukum dalam memberikan ganti kerugian kepada korban agar merasa puas dan sepakat.

Ganti rugi dapat diberikan jika kejadian tersebut memiliki unsurunsur sebagaimana dalam perjanjian yaitu adanya kesanggupan pertanggungjawaban hukum dalam suatu perjanjian, adanya perbuatan melawan hukum terhadap peraturan perundang-undangan, serta adanya kerugian korban yang harus ditanggung.Besaran ganti rugi dapat dilihat didalam perjanjian suatu kesepakatan dengan dasar beriktikad baik pada biaya-biaya fisik dan biaya langsung yang sebagaimana diatur pada Undang-undang Republik Indonesia No. 1 Tahun 2009 Tentang Penerbangan dengan Undang-Undang Republik Indonesia Nomor 21 Tahun 2013 Tentang Keantariksaan.

\section{Ucapan Terima Kasih}

Kepada Bapak/ibu dosen pengampuh mata kuliah Hukum udara dan ruang angkasa prodi Ilmu Hukum Universitas Negeri Surabaya yang telah memberikan bimbingan secara berkala kepada penulis.

\section{Daftar Pustaka}

Abdurrasyid, P. (1972). Kedaulatan

Negara Di Ruang Udara. Jakarta: Pusat Penelitian Hukum Angkasa. 
Suherman, E. (1984). Wilayah Udara dan Wilayah Dirgantara. Bandung: Penerbit Alumni.

Fajar, M. (2010). Dualisme Penelitian Hukum Normatif \& Empiris. Yogyakarta: Pustaka Pelajar.

Johan, E. (2010). Pengaturan

Mengenai Pesawat Udara Militer

Menurut Hukum Udara

Internasional. Perspektif, 15(3),

263.

https://doi.org/10.30742/perspektif .$v 15 \mathrm{i} 3.55$.

Martono. K. (1995). Hukum Udara,Angkutan Udara dan Hukum angkasa, Hukum Laut Internasional,Bandung: Mandar Maju.

Peter, M. 2011.Penelitian Hukum. Jakarta: Kencana Prenada Media Group.

Rosa, A. 2003.PerbuatanMelawan Hukum. Jakarta: Program Pasca Sarjana Fakultas Hukum Universitas Indonesia.

Soerjono, S. (2006).Pengantar Penelitian Hukum. Jakarta: Penerbit Universitas Indonesia. (1986). Pengantar

Penelitian Hukum. Jakarta: UI Press.
Soerjono, S. (2003). Penelitian Hukum Normatif. Jakarta: Raja Grafindo Persada.

Soesilo dan Pramudji, R. (2008).KitabUndang-Undang

Hukum Perdata. Surabaya: Rhedbook Publisher

Undang-Undang Republik Indonesia No. 43 Tahun 2008 Tentang Wilayah Negara

Undang-Undang Republik Indonesia No. 1 Tahun 2009 Tentang Penerbangan

Undang-Undang Republik Indonesia Nomor 21 Tahun 2013 Tentang Keantariksaan

Peraturan Pemerintah Republik Indonesia Nomor 3 Tahun 2001 Tentang Keamanan Dan Keselamatan Penerbangan

Kitab Undang-Undang Hukum Perdata https://www.cnnindonesia.com/nasion al/20200615213941-20-

513635/tni-au-ganti-rugi-rumahwarga-yang-tertimpa-pesawat-diriau Diakses Pada hari senin Tanggal 15 Maret 2021

https://www.merdeka.com/peristiwa/h ercules-jatuh-di-medan-korbanterbanyak-kedua-dalam-sejarah-

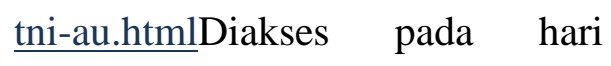
selasa tanggal 16 Maret 2021 